\title{
Identification and characterization of the proteolytic microorganism isolated from salt mackerel
}

\author{
Tae-Hyung Kwon ${ }^{1}$, Jong-Hwa Lee ${ }^{2 *}$ \\ ${ }^{1}$ Department of Research and Development, Chuncheon Bio-Industry Foundation, Chuncheon 24232, Korea \\ ${ }^{2}$ Department of Food Sicence and Biotechnology, Andong National University, Andong 36729, Korea
}

\section{간고등어로부터 분리한 부패성 미생물의 동정 및 생육 특성}

\author{
권태형 ${ }^{1} \cdot$ 이종화 ${ }^{2 *}$ \\ ${ }^{1}$ (재)춘천바이오산업진흥원 기술개발실, ${ }^{2}$ 안동대학교 식품생명공학과
}

\begin{abstract}
Mackerel (Scomber japonicus) is one of the most important cultured marine species on the southern coast of Korea. However, microbiological spoilage of mackerel can occur because of bacteria, yeast, and molds. Therefore, in this study, we investigated the chemical composition of salt mackerel and characterized and identified proteolytic microorganisms isolated from salt mackerel. The moisture, crude protein, crude lipid and crude ash contents of salt mackerel were found to be $62.1 \%, 17.3 \%, 16.3 \%$, and $2.6 \%$, respectively. Eleven microorganism strains were isolated from salt mackerel and characterized to determine the optimum $\mathrm{pH}$ and temperature for their growth and their viability in sodium chloride. Based on determination of $18 \mathrm{~S}$ rRNA genes and 16S rRNA genes. the dominant yeast and bacteria species Rhodotorula glutinis and Escherichia hermannii, respectively. $R$. glutinis and $E$. hermannii showed optimum growth at $25^{\circ} \mathrm{C}, \mathrm{pH} 7.0$ and $8 \%$ and $6 \%$ sodium chloride, respectively.
\end{abstract}

Key words : salt mackerel, microorganism, proteolytic, characterization

서 론

적색어류의 대표적인 고등어는 고등어과에 속하는 바 닷물고기로서 연근해에서 많이 어획되며, 정어리, 전갱 이, 꽁치와 함께 4대 등푸른 생선으로 불린다. 특히 고등 어에는 고도불포화지방산인 eicosapentaenoic acid(EPA)와 docosahexaenoic acid(DHA) 등이 함유되어 있어 뛰어난 생리적 기능성을 가지고 있다. 또한, 양질의 아미노산과 핵산 및 비타민 B, E 등 우수한 영양소를 많이 포함하고 있어 영양적 가치도 높다. EPA나 DHA의 기능성은 혈중 콜레스테롤 저해 효과, 혈전 예방 효과 및 두뇌 작용을 활
성화시키는 건뇌 효과 등이 보고되고 있다(Medina 등, 1996; Nordoy 등, 1993; Simopoulos, 1991). 더불어 최근 식습관의 변화와 사회 발전으로 식생활이 서구화되면서 기능 성 및 건강 증진 효능을 가진 식품류가 주목을 받고 있는 추 세이다(Horrocks and Yeo 1999; Lee 등, 1997).

그러나 고등어는 수분이 많고 조직이 연하며 미생물이 부착되기 쉽고, 취급이 불결하여 육류보다도 더욱 부패하 기 쉽다. 또한, 근육에 비단백태질소 성분이 많이 있어 이 들 성분들이 부패하는 동안 세균에 의해 이용되기 때문에 생선은 다른 고단백들의 근육식품보다 훨씬 변패하기 쉽 다(Shin 등, 2006; Yoon 등, 2007). 더불어 어획 후 선도가

\footnotetext{
*Corresponding author. E-mail : okjhlee@andong.ac.kr, Phone : +82-54-820-5551, Fax : +82-54-780-6264

Received 16 April 2020; Revised 29 May 2020; Accepted 16 June 2020.

Copyright (c) The Korean Society of Food Preservation.

This is an Open Access article distributed under the terms of the Creative Commons Attribution Non-Commercial License (http://creativecommons.org/licenses/by-nc/4.0) which permits unrestricted non-commercial use, distribution, and reproduction in any medium, provided the original work is properly cited.
} 
급속히 저하 되어 유통기간이 짧고 단백질 변성으로 수산 가공품의 원료로 이용하기에 부적합하여 많은 양이 염장 품 또는 사료로 이용되고 있다(Lim 등, 1997). 또한, 단백 질 공급원으로서 중요한 어류는 그 조직학적인 특성과 유 통과정의 어려움으로 인하여 미생물에 의한 부패가 상당 히 문제 되고 있다. 실제로 세균에 의한 오염 및 부패에 관 한 연구보고(Sakada 등, 1980; Shewan, 1971)와 어육과 장 기에 분포하고 있는 단백분해효소에 의한 어육의 사후변 화에 관한 연구가 보고되고 있다(Pyeun 등, 1996; Ueno 등, 1988).

이러한 이유로 미생물에 의해 변질 및 산화가 급속하게 진행되고, 어취가 발생하는 등 가공적성이 낮아 보다 효 율적인 연구가 필요하다 하겠다. 그러나 현재까지 고등어 부패균에 관련된 연구는 미비하며, 고등어와 관련된 연구 중 대부분은 고등어의 품질과 저장성 향상을 위한 방법으 로 저온삼투압 탈수법을 이용(Lee 등, 1993)하거나 반염건 고등어 제조 시 염지 처리 후 셀로판 필름을 포장하여 건조하 는 방법(Ahn 등, 1991), 항균 필름과 저장 온도를 병행하여 안전성 효과(Ha 등, 2007), Brine 처리 효과(Aubourg와 Ugliano, 2002), 포장지의 공기압을 이용한 저장 효과 (Goulas과 Kontominas, 2007), 한방 추출물이나 식물의 추출 물을 이용한 저장성 개선에 중점을 두고 있다(Hong 등, 2005; Jung 등, 2004; Shin 등, 2006).

따라서 본 연구에서는 간고등어 부패에 관련된 균을 분 리하고, 이를 동정하여 근본적인 미생물학적 원인을 분석 하고, 분리된 고등어 부패 균주의 특성을 제시하고자 하 였다.

\section{재료 및 방법}

\section{시료 구입 및 절임 과정}

본 실험 재료인 고등어(Scomber japonicus, mackerel)는 안동시 일직면 송리에 있는 안동 참간고등어에서 구입하였 고, 시료는 무게가 약 200-250 g 정도 되는 고등어를 이용하 여 연구에 사용하였다. 시료의 절임과정은 참간고등에서 진 행되고 있는 방법을 이용하였다(Fig. 1). 즉, 원료의 내장을 제 거하고 흐르는 물에 세척하여 이물질 등을 제거한 후 습식염 장을 하고 1 시간 후 수분을 제거하여 다시 건식 염장을 하였 다. 이후 12-18 h 동안 숙성하여 연구에 사용하였다.

시약은 Sigma(Sigma Chemical Co., St. Louis, MO, USA) 에서 구입하였으며, 간고등어로부터 분리한 부패성 미생물의 동정 및 생육 특성 연구와 관련하여 흡광도는 UV-pharmaspec 1700(Shimadzu, Kyoto, Japan) 및 Spectra max M2(Molecular devices, Sunnyvale, CA, USA)를 이용하여 측정하였다.

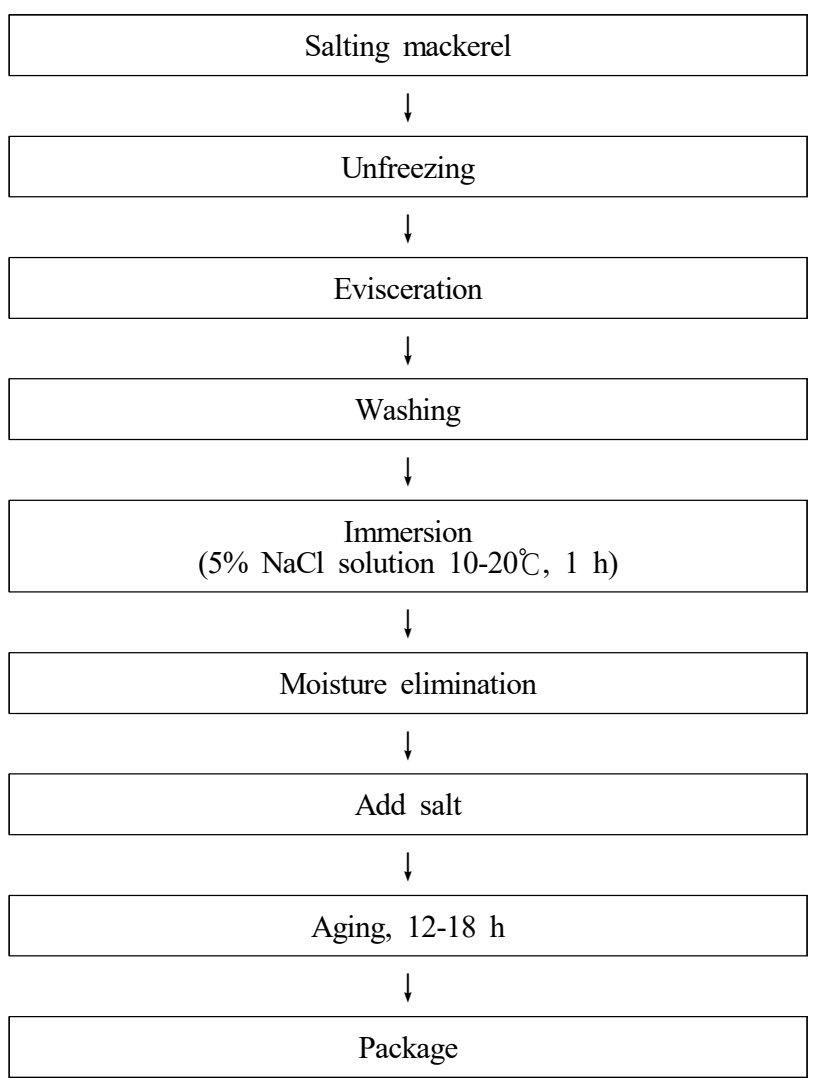

Fig. 1. Preparation method of salt mackerel.

\section{간고등어 일반분석 및 무기함량 분석}

일반성분과 무기성분 분석은 $\mathrm{AOAC}(2000)$ 에 준하여 실험 하였다. 즉, 수분은 $105^{\circ} \mathrm{C}$ 상압가열건조법, 회분은 회화법, 조단백질은 Kjeldahl법, 조지방은 Soxhlet 추출법을 사용하였 다. 즉, 무기함량 분석은 시료 $0.5 \mathrm{~g}$ 에 nitric acid와 $\mathrm{H}_{2} \mathrm{O}_{2}$ 를 넣어 분해시킨 후 Whatman No.2 filter paper (Whatman, Maidstone, Kent, UK)에 여과하였다. 여과된 시료에 증류수 를 가하여 $100 \mathrm{~mL}$ 로 정용하여 Inductively Coupled Plasma Spectrometer(Perkin Elmer Co., Norwalk, CT, USA)를 이용 하여 측정하였다.

\section{신선한 간고등어와 부패한 간고등어의 근육 측정}

Scanning electron microscopy (SEM) 전자현미경을 이용 하여 신선한 고등어와 일정 기간이 지난(부패) 고등어의 근 육을 관찰하였다. 샘플은 근육 부분을 $1 \times 1 \times 1 \mathrm{~cm}$ 의 크기로 멸균된 칼을 이용하여 채취하였다. $2.5 \%$ 의 glutaraldehyde를 이용하여 $4^{\circ} \mathrm{C}$ 에서 2 시간 고정시킨 후 $\mathrm{pH}$ 가 7.2 인 $0.1 \mathrm{M}$ 의 PBS 용액으로 세척하였다. 탈수 후 isoamyl acetate를 처리하 고, $\mathrm{CDP}$ 건조한 후 코팅하여 $\mathrm{SEM}$ 전자현미경(Hitachi S-2500C, Hitachi, Tokyo, Japan)을 이용하여 측정하였다. 


\section{간고등어의 부패성 미생물 분리}

간고등어의 부패균 분리는 $\mathrm{Oh}$ 등(1998)의 방법을 변형하 여 분리하였다. 시료 $1 \mathrm{~g}$ 을 취하여 $0.9 \%(\mathrm{w} / \mathrm{v}) \mathrm{NaCl}$ 을 첨가한 후 homogenizer(Kinematica AG, Luzern, Switzerland)를 이 용하여 균질화 하였고, 균질화된 희석액 $100 \mu \mathrm{L}$ 를 $\mathrm{YM}$ agar $\left(\mathrm{BD}, \operatorname{Difco}^{\mathrm{TM}}\right.$, Becton, Dickinson \& Co., Fraanklin, NJ, USA) 배지와 Nutrient agar(BD, Difco ${ }^{\mathrm{TM}}$, Becton, Dickinson $\& \mathrm{Co}$.)배지에 접종하였다. $25^{\circ} \mathrm{C}$ 에서 $48 \pm 2$ 시간 배양한 후 집 락의 형태상이나 색의 유무, colony 크기에 따라 균을 분리하 였다. 간고등어의 경우, 냉장이나 일반 실온에서 가장 많이 유통되기 때문에 본 연구에서는 $25^{\circ} \mathrm{C}$ 에서 배양하여 가장 부 패에 영향을 미치는 균을 분리하고자 하였다.

\section{간고등어 부패 균주의 동정}

$16 \mathrm{~S}$ rRNA 및 $18 \mathrm{~S}$ rRNA 유전자 염기서열 분석을 통해 최종 분리된 균주의 동정을 실시하였다. 각각의 배지에서 24 시간 동안 배양시킨 배양액을 $10,000 \mathrm{rpm}$ 에서 10 분간 원심분 리하여 균체를 회수하고, Wizard genomic DNA purification kit(Promega, Madison, WI, USA)의 방법에 따라 추출하였 다. 이후 분리된 균주의 동정은 (주마크로젠(Macrogen, Seoul, Korea)에 의뢰하여 염기서열을 해독하였다. 1 개 균주 이상 $100 \%$ 상동성을 가지고 있는 경우에는 bit score 값이 높은 균주를 선택하여 동정하였다.

\section{온도에 따른 균 성장}

분리한 균으로부터 증식에 영향을 미치는 인자에 대한 특 성을 조사하였다. 분리한 균을 YM agar 배지 및 Nutrient agar 배지에 streaking하여 $25^{\circ} \mathrm{C}$ 에서 배양한 후 $\mathrm{YM}$ broth 및 Nutrient broth 배지를 만들어 균을 일정한 농도 $\left(10^{5} \log \right.$ $\mathrm{CFU} / \mathrm{mL}$ )로 접종하였다. Shaking incubator를 이용하여 10 , $15,20,25,30,37^{\circ} \mathrm{C}$ 에 2 일 동안 배양했으며, rpm은 150 으로 맞추었고, 6시간마다 $540 \mathrm{~nm}$ 에서 흡광도를 측정하였다.

\section{$\mathrm{pH}$ 에 따른 균 성장}

최적 $\mathrm{pH}$ 는 $0.1 \mathrm{M}$ 시트르산 완충용액( $\mathrm{pH} 4.0-5.0), 0.1 \mathrm{M}$ 인산 완충용액(pH 6.0-7.5), 0.1 M Tris 완충용액( $\mathrm{pH}$ 8.0-9.0) 을 사용하여 각각 4.0-8.0의 범위로 $\mathrm{pH}$ 조정한 $\mathrm{YM}$ broth와 Nutrient broth 배지에 일정한 농도 $\left(10^{5} \log \mathrm{CFU} / \mathrm{mL}\right)$ 로 분리 한 균을 접종하고, $25^{\circ} \mathrm{C}$ 에서 48 시간 배양하여 $540 \mathrm{~nm}$ 에서 흡광도를 측정하였다.

\section{$\mathrm{NaCl}$ 함량에 따른 균 성장}

분리된 미생물로부터 염 농도에 따른 균주의 성장 여부를 파악하기 위해 균을 일정한 농도 $\left(10^{5} \log \mathrm{CFU} / \mathrm{mL}\right)$ 로 100배
희석한 후 $\mathrm{NaCl}$ 의 농도를 달리한 tube에 접종하여 $25^{\circ} \mathrm{C}$ shaking incubator에서 4일간 배양 후 $600 \mathrm{~nm}$ 에서 흡광도를 측정하였다.

\section{결과 및 고찰}

\section{간고등어의 일반성분 및 무기함량}

간고등어의 일반성분을 $\mathrm{AOAC}$ 법을 이용하여 측정한 결과 (Table 1) 수분함량이 $62.1 \pm 3.2 \%$ 로 가장 많았고 조단백질과 조 지방은 각각 $17.3 \pm 2.8,16.3 \pm 2.1 \%$, 조회분 함량은 $2.6 \pm 0.8 \%$ 로 측정되었다. Park 등(1997)에 따르면 고등어의 체중과 계절, 암수, 어장 등 자연적인 환경과 생태계의 차이에 따라 다소 차이가 있는 것으로 보고하고 있으며, 보통 선어의 경우 수분 함량이 64-76\% 정도 되는 것으로 보고하고 있다(Park 등, 1997). Song 등(2005)에 의하면 수분함량의 경우 좀 더 낮은 $43.94 \%$ 이며, 조단백질과 조지방의 경우 각각 $18.87 \%$, $33.75 \%$ 로 보고하고 있다(Song 등, 2005). 이는 본 연구에서 는 수분함량, 조회분의 경우는 Park 등의 연구와 전체적으로 유사한 경향을 보였다. 조지방과 조단백질 함량에 있어서도 큰 차이는 나타나지 않았다. 그러나 Nam 등(2011)은 본 연구 와는 약간의 차이를 보였다. 이는 고등어의 지방함량이 계절 에 따라 영향을 많이 받기 때문일 것으로 사료 된다.

무기질 함량 분석은 ICP를 이용하여 분석하였다(Table 2). 나트륨과 칼륨이 약 $4.27 \pm 0.3,4.34 \pm 0.8 \mathrm{mg} / \mathrm{g}$ 으로 각각 가장 많은 함량을 보였고, 마그네슘, 칼슘 순으로 측정되었으며, 각 각 $0.24 \pm 0.02,0.15 \pm 0.04 \mathrm{mg} / \mathrm{g}$ 함유하고 있었다. 또한, $\mathrm{Ti}, \mathrm{V}$ 및 $\mathrm{Ba}$ 는 측정되지 않았으며, 본 연구에서 $\mathrm{LOD}$ 및 $\mathrm{LOQ}$ 는 $100 \mathrm{ppb}$ 로 설정하였다. 본 연구 결과는 기장과 완도에서 해 양 생물인 다시마의 무기성분 함량 분석에서 $\mathrm{Na}, \mathrm{K}$ 가 가장 많이 함유되어 있다는 내용과 동일한데, 해양환경에 의한 특 징일 것으로 사료된다(Choi 등, 2008).

\section{신선 간고등어와 부패 간고등어의 근육}

간고등어의 부패에 따른 근육 조직의 변화를 SEM 전자 현 미경을 이용하여 관찰하였다. 간고등어의 조직 관찰을 위해 (A)의 시료는 1,000 배 배율로 측정하였고, $(\mathrm{B})$ 의 시료는 50 배 배율로 측정하였다. 신선한 어육인 경우(A)에는 표면에 물방 울이 맺혀있으며 표면에 갈라지는 현상이 없이 반들반들한 모

Table 1. Proximate composition of salt mackerel

\begin{tabular}{ccccc}
\hline \multirow{2}{*}{$\begin{array}{c}\text { Component } \\
(\%)\end{array}$} & Moisture & $\begin{array}{c}\text { Crude } \\
\text { protein }\end{array}$ & $\begin{array}{c}\text { Crude } \\
\text { lipid }\end{array}$ & $\begin{array}{c}\text { Crude } \\
\text { ash }\end{array}$ \\
\cline { 2 - 5 } & $62.1 \pm 3.2^{1)}$ & $17.3 \pm 2.8$ & $16.3 \pm 2.1$ & $2.6 \pm 0.8$ \\
\hline
\end{tabular}

${ }^{1)}$ Mean \pm SD $(n=3)$. 
Table 2. Mineral content of salt mackerel

\begin{tabular}{cccccccccccccc}
\hline & $\mathrm{Al}$ & $\mathrm{Ti}$ & $\mathrm{Cr}$ & $\mathrm{Cu}$ & $\mathrm{Ba}$ & $\mathrm{Ca}$ & $\mathrm{Mg}$ & $\mathrm{Fe}$ & $\mathrm{Zn}$ & $\mathrm{Na}$ & $\mathrm{K}$ & $\mathrm{V}$ \\
\hline $\mathrm{mg} / \mathrm{g}$ & $0.15 \pm 0.04^{1)}$ & $\mathrm{ND}^{2)}$ & $0.02 \pm 0.00$ & $0.02 \pm 0.00$ & $\mathrm{ND}$ & $0.17 \pm 0.05$ & $0.24 \pm 0.02$ & $0.02 \pm 0.00$ & $0.004 \pm 0.00$ & $4.27 \pm 0.3$ & $4.30 \pm 0.8$ & $\mathrm{ND}$ \\
\hline
\end{tabular}

${ }^{1)} \mathrm{Mean} \pm \mathrm{SD}(\mathrm{n}=3)$.

${ }^{2)} \mathrm{ND}$, not detected.

습을 보이나, 어육이 부패되어 신선하지 않은 경우(B)에는 표 면에 반들반들한 부분이 사라지고 갈라지는 모습이 발생하였 다(Fig. 2). 이러한 결과는 참치 근육 구조에서 부패 시 근육의 근섬유가 붕괴되고, 또한 명태의 장기간 저장 시 myofilament 가 응집하고 스폰지화가 일어나는 것으로 보고(Yun과 Lee, 1997)된 연구와 유사한 경향을 보였다.

또한, Yoon 등(2007)은 간고등어의 저장 중 조직도를 검사 한 결과, 저장 기간에 따라 점착성, 점성도가 떨어지고, 경도 가 감소하는 것으로 보고 하였다(Yoon 등, 2007). 이 결과를 토대로 본 연구의 결과를 유추해보면 조직감의 전체적인 감소 로 인해 신선한 어육에 비해 부패 어육이 갈라짐이나 조직의 붕괴가 급속히 일어날 것으로 사료 된다.

\section{간고등어의 부패성 미생물 분리 동정}

시료를 균질화한 후 $1 \mathrm{~g}$ 을 취하고 $0.9 \% \mathrm{NaCl}$ 을 첨가한 후 homogenizer(Kinematica $\mathrm{AG}$ )로 균질화 하였고, $\mathrm{YM}$ agar 와 Nutrient agar를 이용하여 효모와 세균을 분리하였다. $25^{\circ} \mathrm{C}$ 에서 $48 \pm 2$ 시간 배양하였으며, 형태상이나 색의 유무, colony 의 크기 등에 의해 균주를 분리하였다. 또한, 간고등어의 부
패에 미치는 균을 알아보기 위하여 ribosomal RNA 서열분석 을 이용하였고, 그 결과는 Table 3에 나타내었다. YA는 Rhodotorula glutinis로 동정 되었으며, Rhodotorula 속은 해 양에 많이 존재하며, 지방 축적력이 강한 것으로 알려져 있다. $\mathrm{YB}$ 는 Saccharomyces cerevisiae, $\mathrm{YG}$ 는 Saccharomyces sp. 로 동정되었으며, 한편 세균의 경우 $\mathrm{BA}$ 및 $\mathrm{BB}$ 는 Escherichia hermannii, $\mathrm{BC}$ 는 Staphylococcus caseolyticus로 동정되었다. 한편, Oh 등(1998)의 보고에 의하면 YM agar 배지를 이용하 여 효모를 분리한 결과 총 14 종의 효모를 분리하였고, 그 결 과 본 연구와 동일하게 Candida 속과 Rhodotorula 속이 분리 가 되었다는 보고와 유사했으며, 이 두 균주는 해양에 다양하 게 존재하고 있는 것으로 알려져 있다. 또한, Cryptococcus 속, Trichosporon속 등을 분리한 것으로 보고하였다.

\section{간고등어 부패 균주의 온도에 따른 영향}

효모 증식에 영향을 미치는 인자로서는 온도, $\mathrm{pH}$, 식염 등이 있다. 간고등어로부터 분리한 균의 온도에 따른 특 성을 살펴보기 위하여 분리한 균을 shaking incubator 10 , $15,20,25,30,37^{\circ} \mathrm{C}$ 에 2 일 동안 배양하였으며, $\mathrm{rpm}$ 은 150
(A)

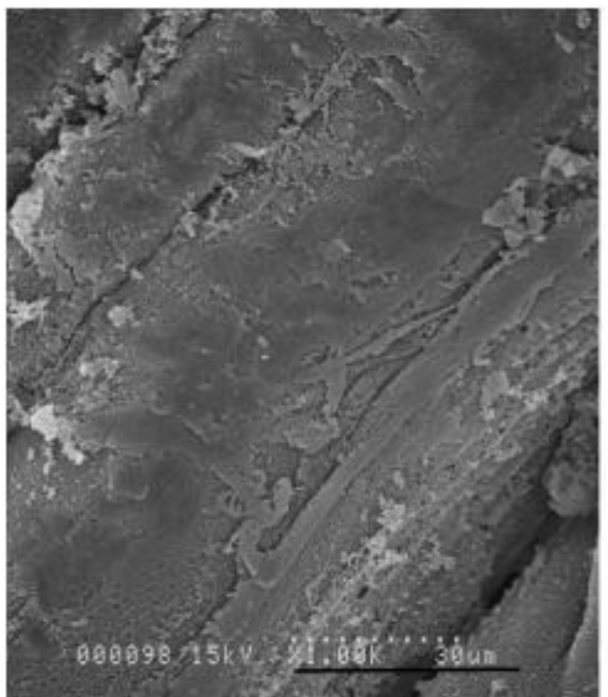

(B)

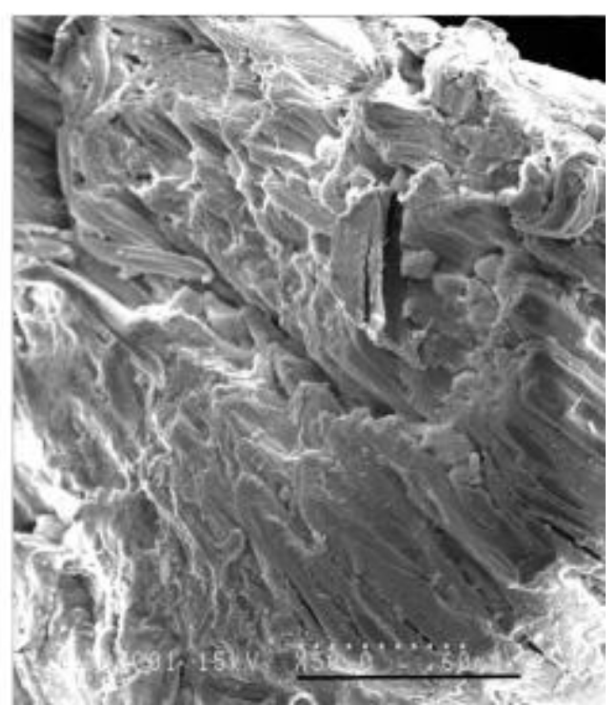

Fig. 2. Scanning electron microscope images of fresh and proteolytic salt mackerel muscle.

A, fresh salt mackerel $\times 1,000$; $\mathrm{B}$, proteolytic salt mackerel $\times 50$. 
Table 3. Identification of yeast and bacteria isolated from salt mackerel

\begin{tabular}{|c|c|c|c|}
\hline Strains $^{1)}$ & Identification & Strains & Identification \\
\hline $\mathrm{Y}^{2)} \mathrm{A}$ & Rhodotorula glutinis & $\mathrm{B}^{3)} \mathrm{A}$ & Escherichia hermannii \\
\hline YB & $\begin{array}{l}\text { Saccharomyces } \\
\text { cerevisiae }\end{array}$ & BB & Escherichia hermannii \\
\hline $\mathrm{YC}$ & Candida zeylanoides & $\mathrm{BC}$ & $\begin{array}{l}\text { Staphylococcus } \\
\text { caseolyticus }\end{array}$ \\
\hline YD & $\mathrm{ND}^{4)}$ & & \\
\hline YE & ND & & \\
\hline YF & $\begin{array}{c}\text { Saccharomyces } \\
\text { boulardii }\end{array}$ & & \\
\hline YG & Saccharomycete sp. & & \\
\hline YH & ND & & \\
\hline
\end{tabular}

${ }^{1)}$ YA, Rhodotorula glutinis; YB, Saccharomyces cerevisiae; YC, Candida zeylanoides; YD, unidentified organism; YE, unidentified organism; YF, Saccharomyces boulardii; YG, Saccharomycete sp.; YH, unidentified organism; BA, Escherichia hermannii; BB, Escherichia hermannii; BC, Staphylococcus caseolyticus.

${ }^{2)} \mathrm{Y}$, yeast.

${ }^{3)} \mathrm{B}$, bacteria.

${ }^{4)} \mathrm{ND}$, not detected.
으로 하였고, $540 \mathrm{~nm}$ 에서 흡광도를 측정하였으며, 48시간 배양 후 온도에 따른 영향을 Fig. 3에 나타내었다. 분류된 균마다 생육 특성은 약간씩 다르게 나타났다. 그 결과, 효모 의 경우 $20-25^{\circ} \mathrm{C}$ 사이의 중온에서 가장 성장도가 높았으나, $10^{\circ} \mathrm{C}$ 나 $37^{\circ} \mathrm{C}$ 에서는 균의 성장률이 낮았다. 한편, 세균은 $\mathrm{BA}$, $\mathrm{BB}, \mathrm{BC}$ 모두 공통적으로 $37^{\circ} \mathrm{C}$ 의 중온에서 성장 속도가 높았 으며, 오히려 효모와는 달리 저온에서 잘 자라지 않았고 온도 가 낮을수록 성장률이 낮은 결과를 보였다. 고등어에서 균을 분리한 연구는 아직 미비하며, Oh 등(1998)의 연구에 의하면 고등어에서 분리하여 균의 최적온도를 측정한 결과와 비슷한 것을 알 수 있다(Oh 등, 1998). 그러나 $\mathrm{YG}, \mathrm{BB}$ 는 $10^{\circ} \mathrm{C}$ 의 저 온에서도 균 성장률이 $40 \%$ 이상으로 잘 자랐으며, 다른 균들 또한 저온에서도 성장을 하는 것으로 보아, 분리한 균이 간고 등어의 품질에 영향을 끼칠 수 있을 것으로 사료된다.

\section{간고등어 부패 균주의 $\mathrm{pH}$ 에 따른 영향}

효모 및 세균 증식에 영향을 미치는 인자 중 $\mathrm{pH}$ 에 따른 균의 성장 변화를 연구하였다. 효모 $\mathrm{YA}, \mathrm{YB}, \mathrm{YC}$ 는 $\mathrm{pH} 7$ 에서 가장 잘 자랐고, $\mathrm{pH} 5.0$ 에서 가장 낮은 성장률을 보 였다. $\mathrm{YB}$ 는 $\mathrm{pH} 10$ 에서 가장 낮은 성장률을 보였고, $\mathrm{YC}$ 는

(A) Yeast
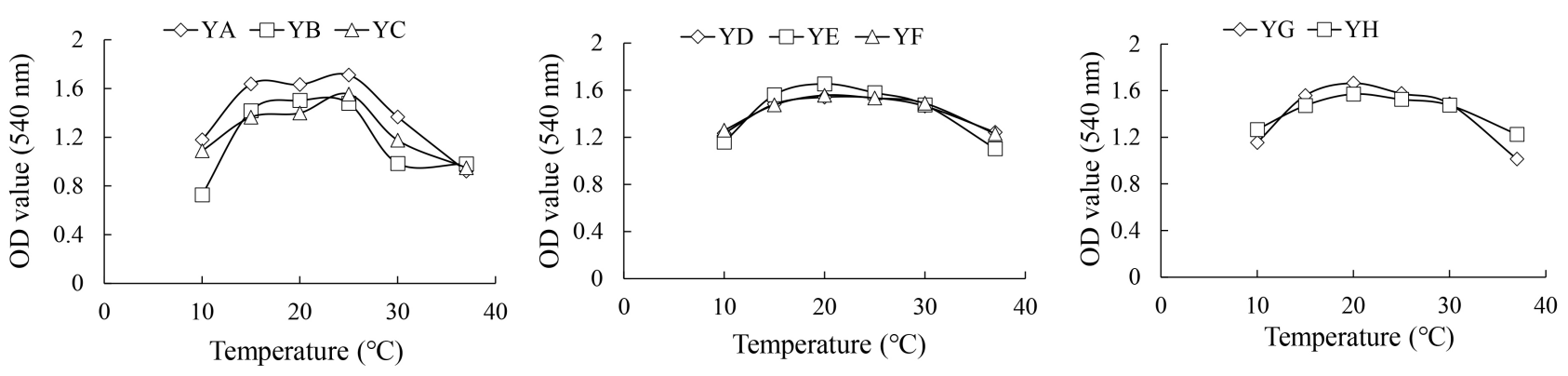

(B) Bacteria

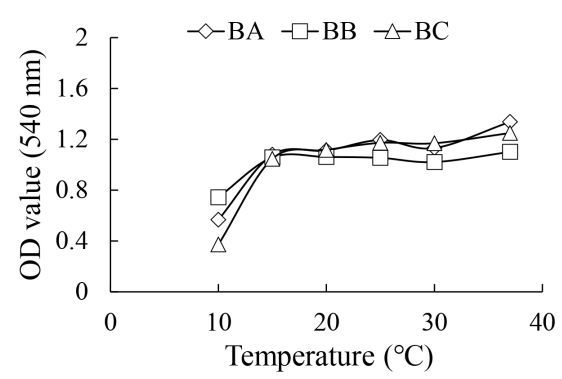

Fig. 3. Effects of temperature on the growth of yeast (A) and bacteria (B) in YM, nutrient broth medium for $48 \mathrm{~h}$.

YA, Rhodotorula glutinis; YB, Saccharomyces cerevisiae; YC, Candida zeylanoides; YD, unidentified organism; YE, unidentified organism; YF, Saccharomyces boulardii; YG, Saccharomycete sp.; YH, unidentified organism; BA, Escherichia hermannii; BB, Escherichia hermannii; BC, Staphylococcus caseolyticus. 
$\mathrm{pH}$ 4.0와 5.0에서 낮은 성장률을 보였다. 한편, $\mathrm{YD}$ 는 $\mathrm{pH}$ 4에서 가장 높은 성장률을 보였으나, $\mathrm{YA}, \mathrm{YB}, \mathrm{YC}$ 와 달리 높은 $\mathrm{pH}$ 에서는 성장률이 낮아서 상반된 결과를 보였다. $\mathrm{YG}$ 는 $\mathrm{pH}$ 6에서 균의 성장이 가장 높았으며, 낮은 $\mathrm{pH}$ 인 4 와 5 에 서 성장률이 가장 낮았다. 전체적으로 효모의 경우 $\mathrm{YD}$ 를 제 외한 나머지는 $\mathrm{pH}$ 중성 부위에서 가장 높은 성장을 보였고, $\mathrm{YD}$ 는 $\mathrm{pH}$ 가 낮은 쪽에서 가장 높은 성장을 보였다. 한편, 세 균은 $\mathrm{BA}, \mathrm{BB}$ 모두 $\mathrm{pH} 7.0$ 인 중성 부위에서 가장 높은 성장 을 보였으며, $\mathrm{pH} 4.0$ 와 5.0에서 가장 낮은 성장률을 보였다 (Table 4). 또한, $\mathrm{pH}$ 가 중성이 아닌 너무 낮거나 높아질 때 균의 성장은 미비하게 나타났다. 본 연구는 Oh 등(1998)이 분리한 효모 중 C. lipolytica FM5의 최적 $\mathrm{pH}$ 는 6.5-7.5에서 가장 성장이 높다는 연구와 동일하였다(Oh 등, 1998). 이는 Song 등(2005)에 의하면 신선한 고등어 경우 $\mathrm{pH}$ 가 5-6 사이 인데, 부패가 될수록 $\mathrm{pH}$ 가 높아지는 것으로 보고하고 있다 (Song 등, 2005). 이는 곧 처음보다 고등어가 부패 되면서 균 의 급성장이 이루어지는 최적 $\mathrm{pH}$ 가 형성이 되어 급속도로 부 패가 진행되는 것으로 추정할 수 있다.

\section{간고등어 부패 균주의 $\mathrm{NaCl}$ 함량에 따른 영향}

균의 증식에 영향을 미치는 인자 중 하나인 식염 함량 에 따른 균의 성장변화를 연구하였다. 균을 일정한 농도 $\left(10^{5} \log \mathrm{CFU} / \mathrm{mL}\right)$ 로 100 배 희석한 후 $\mathrm{NaCl}$ 의 농도를 달리 한 tube에 접종하여 $25^{\circ} \mathrm{C}$ shaking incubator에서 4 일간 배
양 후 $600 \mathrm{~nm}$ 에서 흡광도를 측정하였다. 염농도를 달리 하여 저염부터 고염까지 균 성장의 유무를 측정하기 위하 여 $0,2,4,6,8,10 \%$ 별로 측정하였으며, 그 결과는 Table 5 와 같다. 대부분의 균이 6-10\% 함량에서 증식이 되었고, 비 교적 높은 $10 \%$ 의 함량에서도 잘 자라는 것으로 보아 강한 내염성을 가지고 있는 것으로 생각된다. $\mathrm{YA}, \mathrm{YC}, \mathrm{YE}, \mathrm{TF}$, $\mathrm{YG}$ 가 $6-10 \%$ 함량에서 높은 성장을 보였고, $\mathrm{YH}$ 는 $2 \%$ 에서 잘 성장하였다. 세균은 효모보다는 다소 낮은 염의 농도에서 잘 성장하는 형태를 보였으며, 균마다 특성은 다른 것으로 추 정된다. 세균 $\mathrm{BA}$ 는 $6 \%$ 에서, $\mathrm{BB}$ 는 $10 \%, \mathrm{BC}$ 는 $0 \%$ 에서 0.67 , $0.55,0.55$ 로 가장 높게 측정되었고, $\mathrm{BA}, \mathrm{BB}$ 는 저농도로 갈 수록 $\mathrm{OD}$ 값이 낮았으며, $\mathrm{BC}$ 의 경우는 고농도에서 흡광도 값 이 낮았다. 한편, $\mathrm{Oh}$ 등(1998)은 $10 \%$ 에서도 성장이 잘 되는 것으로 보고되고 있으며 이번 연구에서 비슷한 경향을 보였 다(Oh 등, 1998). 현재 고등어로부터의 균 분리 및 특성에 관 한 연구는 미비하며, 자세한 비교는 불가능하였다. 한편, 염 농도가 낮은 곳에서보다 염 농도가 높은 곳에서도 잘 자라는 것으로 보아 내성이 강하다고 생각되며, 대부분의 균이 높은 염의 농도에서도 균의 성장률이 높았다. 이로 인해 분리한 균 의 특성은 염의 내성이 높은 곳에서도 활발한 증식을 하는 것으로 측정되었으며, 이러한 균이 직접적인 부패에 관여할 것으로 사료된다. Hwang과 $\operatorname{Kim}(2005)$ 은 자반고등어에서 histamine을 분해하는 능력을 가진 세균을 분리하였으며, 해 양에 관련된 세균이 많은 것으로 연구하였다(Hwang과 Kim,

Table 4. Effect of $\mathrm{pH}$ on the growth of yeast and bacteria in YM and nutrient broth

$\left(\mathrm{OD}_{540}\right)$

\begin{tabular}{|c|c|c|c|c|c|c|}
\hline \multirow{2}{*}{\multicolumn{2}{|c|}{ Strain $^{1)}$}} & \multicolumn{5}{|c|}{$\mathrm{pH}$} \\
\hline & & \multirow{2}{*}{$\begin{array}{c}4 \\
0.114\end{array}$} & \multirow{2}{*}{$\frac{5}{0.025}$} & \multirow{2}{*}{$\begin{array}{c}6 \\
0.135\end{array}$} & \multirow{2}{*}{$\begin{array}{c}7 \\
0.611\end{array}$} & \multirow{2}{*}{$\begin{array}{c}8 \\
0.071\end{array}$} \\
\hline Yeast & YA & & & & & \\
\hline & YB & 0.364 & 0.142 & 1.292 & 1.421 & 0.338 \\
\hline & YC & 0.034 & 0.133 & 2.011 & 2.142 & 1.820 \\
\hline & YD & 1.345 & 1.320 & 1.232 & 0.403 & 0.794 \\
\hline & YE & 0.137 & 0.685 & 1.086 & 1.212 & 0.663 \\
\hline & $\mathrm{YF}$ & 0.160 & 0.969 & 0.992 & 1.211 & 0.831 \\
\hline & YG & 0.444 & 0.793 & 2.408 & 1.165 & 1.227 \\
\hline & YH & 0.100 & 0.737 & 0.982 & 0.944 & 0.639 \\
\hline \multirow[t]{3}{*}{ Bacteria } & BA & 0.373 & 1.042 & 1.088 & 1.454 & 1.156 \\
\hline & BB & 0.550 & 0.947 & 0.972 & 1.291 & 0.869 \\
\hline & $\mathrm{BC}$ & 0.141 & 0.665 & 0.747 & 0.932 & 0.644 \\
\hline
\end{tabular}

${ }^{1)}$ YA, Rhodotorula babjevae; YB, Saccharomyces cerevisiae; YC, Candida zeylanoides; YD, unidentified organism; YE, unidentified organism; YF, Saccharomyces boulardii; YG, Saccharomycete sp.; YH, unidentified organism; BA, Escherichia hermannii; BB, Escherichia hermannii; BC, Staphylococcus caseolyticus. 
Table 5. Effect of salt concentration on the growth of yeast and bacteria in $\mathrm{YM}$ and nutrient broth medium at $25^{\circ} \mathrm{C}$ for $96 \mathbf{h} \quad\left(\mathrm{OD}_{600}\right)$

\begin{tabular}{|c|c|c|c|c|c|c|c|}
\hline \multirow{2}{*}{\multicolumn{2}{|c|}{ Strain ${ }^{1)}$}} & \multicolumn{6}{|c|}{ After 4 days } \\
\hline & & \multirow{2}{*}{$\begin{array}{c}0 \% \\
0.862\end{array}$} & \multirow{2}{*}{$\frac{2 \%}{0.914}$} & \multirow{2}{*}{$\begin{array}{c}4 \% \\
0.786\end{array}$} & \multirow{2}{*}{$\begin{array}{c}6 \% \\
0.821\end{array}$} & \multirow{2}{*}{$\begin{array}{c}8 \% \\
0.985\end{array}$} & \multirow{2}{*}{$\begin{array}{r}10 \% \\
0.802\end{array}$} \\
\hline Yeast & YA & & & & & & \\
\hline & YB & 0.938 & 0.843 & 0.835 & 0.770 & 0.801 & 0.934 \\
\hline & $\mathrm{YC}$ & 0.556 & 0.556 & 0.562 & 0.549 & 0.576 & 0.618 \\
\hline & YD & 0.719 & 0.737 & 0.673 & 0.770 & 0.739 & 0.783 \\
\hline & YE & 0.677 & 0.711 & 0.744 & 0.676 & 0.845 & 0.681 \\
\hline & YF & 0.817 & 0.786 & 0.794 & 0.886 & 0.82 & 0.697 \\
\hline & YG & 0.796 & 0.82 & 0.853 & 0.888 & 0.788 & 0.792 \\
\hline & YH & 0.812 & 0.901 & 0.728 & 0.804 & 0.875 & 0.898 \\
\hline \multirow[t]{3}{*}{ Bacteria } & BA & 0.485 & 0.507 & 0.504 & 0.675 & 0.533 & 0.497 \\
\hline & $\mathrm{BB}$ & 0.489 & 0.503 & 0.483 & 0.499 & 0.542 & 0.551 \\
\hline & $\mathrm{BC}$ & 0.500 & 0.485 & 0.498 & 0.389 & 0.442 & 0.450 \\
\hline
\end{tabular}

${ }^{1)}$ YA, Rhodotorula glutinis; YB, Saccharomyces cerevisiae; YC, Candida zeylanoides; YD, unidentified organism; YE, unidentified organism; YF, Saccharomyces boulardii; YG, Saccharomycete sp.; YH, unidentified organism; BA, Escherichia hermannii; BB, Escherichia hermannii; BC, Staphylococcus caseolyticus.

2005). 또한, 높은 농도에서도 균의 성장이 이루어지는 것으 로 보고하였으며, 최적온도에서도 $25^{\circ} \mathrm{C}$ 에서 균의 성장이 높 은 것으로 측정되어 본 연구와 유사한 것으로 측정되었다.

\section{요 약}

본 연구의 주된 목적은 간고등어의 저장성 향상을 위한 부패에 관련된 미생물을 분리하고, 그들의 생육특성을 보 고하여 저장성 향상을 위한 기초 자료로 제시하고자 하였 다. 이러한 부패에 관련된 균을 분리하여 균성장에 영향을 미 치는 인자 중 염 농도에 따른 균 성장의 경우 $8-10 \%$ 의 농도 에서도 잘 성장하였으며, 최적온도의 경우 분리된 효모는 $20-25^{\circ} \mathrm{C}$ 에서 세균의 경우는 $30-37^{\circ} \mathrm{C}$ 에서 가장 성장률이 높게 나타났으나, 저온에서도 균의 성장이 이루어지는 것으로 보 아 품질의 향상 및 부패에 많은 영향을 끼칠 것으로 사료된 다. 분리한 균의 최적 $\mathrm{pH}$ 의 경우 대부분 중성인 $\mathrm{pH} 7.0$ 에서 성장률이 가장 높았다. 분리한 균은 해양에 주로 존재하는 Rhodotorula glutinis 및 Candida, Saccharomyces cerevisiae 등과 같은 효모 및 Escherichia hermannii, Staphylococcus caseolyticus로 동정되었다.

최근 소비자들의 풍습과 인식의 변화로 인해 합성산화 방지제보다는 천연에서부터 얻은 물질을 이용하여 저장 성 증가를 높이는 연구가 많이 진행되고 있다. 이상의 결 과로 보아 본 연구는 저장성 증가를 높이는 연구에 있어
중요한 기초 자료가 될 것으로 사료되며, 연구 결과로 미 루어 볼 때 위와 같이 분리된 균들에 대하여 항균 활성이 강하고 항산화 효능이 뛰어난 천연물의 경우 간고등어의 저장성을 증가하는데 큰 도움이 될 것으로 사료된다.

\section{Conflict of interests}

The authors declare no potential conflict of interest.

\section{ORCID}

Tae-Hyung Kwon https://orcid.org/0000-0002-2250-9444 Jong-Hwa Lee https://orcid.org/0000-0001-6544-724X

\section{References}

Ahn CB, Kim BG, Lee CH, Lee HY, Lee EH. The effect of cellophane film packing on quality of semi-salted and dried mackerel during processing and storage. J Korean Soc Food Sci Nutr, 20, 139-147 (1991)

AOAC. Official Methods of Analysis. 15th ed, Association of Official Analytical Chemists, Washington DC, USA (2000)

Aubourg SP, Ugliano M. Effect of brine pre-treatment on 
lipid stability of frozen horse mackerel (Trachurus trachurus). Eur Food Res Technol, 215, 91-95 (2002)

Choi JS, Shin SH, Ha YM, Kim YC, Kim TB, Park SM, Choi IS, Song HJ, Choi YJ. Mineral contents and physiological activities of dried sea tangle (Laminaria japonica) collected from Gijang and Wando in Korea. J Life Sci, 18, 474-481 (2008)

Goulas AE, Kontominas MG. Effect of modified atmosphere packaging and vacuum packaging on the shelf-life of refrigerated chub mackerel (Scomber japonicus): Biochemical and sensory attributes. Eur Food Res Technol, 224, 545-553 (2007)

Ha JH, Lee US, Heo SK, Bae DH, Park SK, Hwang SS, Ha SD. Combined effects of antibacterial film and storage temperature on shelf-life and microbiological safety of mackerel. J Fd Hyg Safety, 22, 317-322 (2007)

Hong JY, Nam HS, Huh SM, Shin SR. Changes on the rheology of salted mackerel by treatment of Korean herbal extracts and methods of storage. Korean J Food Preserv, 12, 578-582 (2005)

Horrocks LA, Yeo YK. Health benefits of docosahexaenoic acid (DHA). Pharmacol Res, 40, 211-225 (1999)

Hwang SJ, Kim YM. Isolation and identification of a histamine-degrading bacteria from salt mackerel. J Life Sci, 15, 743-748 (2005)

Jung BM, Chung GH, Jang MS, Shin SU. Quality characteristics of citron treated mackerel oil and fillet during refrigerated storage. Korean J Food Sci Technol, 36, 574-579 (2004)

Lee HA, Yoo IJ, Lee BH. Research and development trends of omega-3 fatty acid fortified foodstuffs. J Korean Soc Food Sci Nutr, 26, 161-174 (1997)

Lee JS, Joo DS, Kim JS, Cho SY, Lee EH. Processing of a good quality salted and semi-dried mackerel by high osmotic pressure resin dehydration under cold condition. Korean J Food Sci Technol, 25, 468-474 (1993)

Lim CY, Lee SJ, Lee IS, Kim JG, Sung NJ. The formation of N-nitrosamine during storage of salted mackerel, Scomber japonicus. J Korean Soc Food Sci Nutr, 26, 45-53 (1997)

Medina AR, Gimenez AG, Camacho FG, Perez JAS, Grima EM, Gomez AC. Concentration and purification of stearidonic, eicosapentaenoic, and docosahexaenoic acids from cod liver oil and the marine microalga Isochrysis galbana. J Am Oil Chem Soc, 72, 575-583 (1995)
Nam KH, Jang MS, Lee DS, Yoon HD, Park HY. Effect of green tea and lotus leaf boiled water extracts treatment on quality characteristics in salted mackerel during storage. Korean J Food Preserv, 18, 643-650 (2011)

Nordoy A, Hatcher LF, Ullmann DL, Connor WE. Individual effects of dietary saturated fatty acids and fish oil on plasma lipids and lipoproteins in normal men. Am $\mathrm{J}$ Clin Nutr, 57, 634-639 (1993)

Oh EG, Park MY, Chang DS. Proteolytic yeasts isolated from mackerel (Scomber japonicus). J Korean Fish Soc, 31, 471-476 (1998)

Park YH, Jang DS, Kim ST. Processing and Using of Fishery Science. Hyungseol Press, Seoul, Korea, p 73 (1997)

Pyeun JH, Lee DS, Kim DS, Heu MS. Activity screening of the proteolytic enzymes responsible for post-mortem degradation of fish tissues. J Korean Fish Soc, 29, 296-308 (1996)

Sakata T, Nakaji M, Kakimoto D. Microflora in the digestive tract of marine fish-I: general characterization of the isolates from yellow tail. Mem Fac Fish Kagoshima Unvi, 27, 65-71 (1978)

Shewan JM. The microbiology of fish and fishery products a progress report. J Appl Bact, 34, 299-315 (1971)

Shin SR, Hong JY, Nam HS, Huh SM, Kim KS. Chemical changes of salted mackerel by Korean herbal extracts treatment and storage methods. Korean J Food Preserv, 13, 18-23 (2006)

Simopoulos AP. Omega-3 fatty acids in health and disease and in growth and development. Am J Clin Nutr, 54, 438-463 (1991)

Song HN, Lee DG, Han SW, Yoon HK, Hwang IK. Quality changes of salted and semi-dried mackerel fillets by UV treatment during refrigerated storage. Korean $\mathrm{J}$ Food Cookery Sci, 21, 662-668 (2005)

Ueno R, Sakanaka K, Ikeda S, Horoguchi Y. Purification of pepstatin insensitive protease from mackerel white muscle. Nippon Suisan Gakkaishi, 54, 691-697 (1988)

Yoon KY, Hong JY, Kim MH, Cho YS, Shin SR. Changes on the characteristics of salted mackerel treated extracts of edible plants during storage. Korean J Food Preserv, 14, 439-444 (2007)

Yun JU, Lee SH. Studies on the histological changes of pacific saury (Cololabis saira) by the salting, freezing, thawing and heating. J Korean Soc Ind Food Technol, 1, 86-93 (1997) 